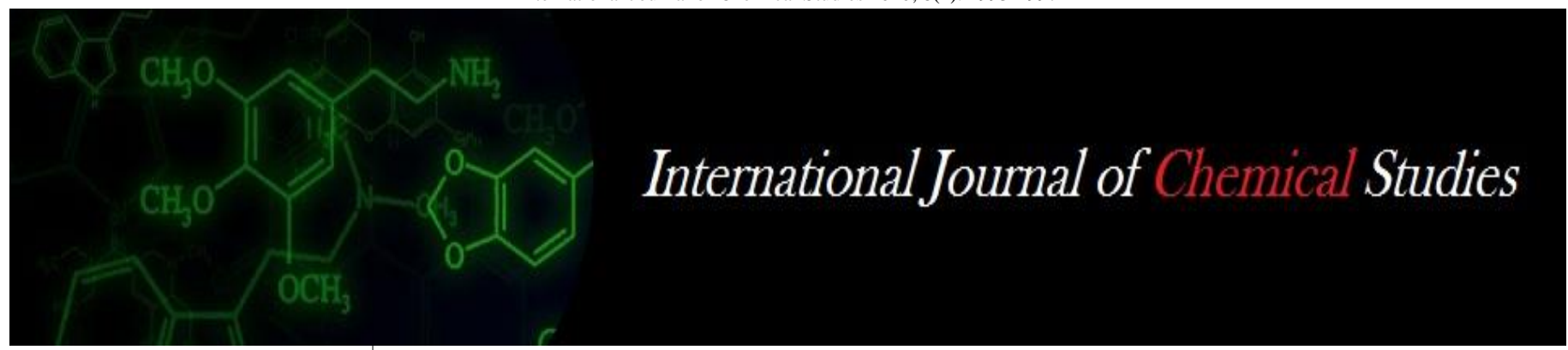

P-ISSN: 2349-8528

E-ISSN: 2321-4902

www.chemijournal.com

IJCS 2020; 8(4): 1993-1997

(C) 2020 IJCS

Received: 22-05-2020

Accepted: 24-06-2020

\section{Mastan Vali}

Department of Plantation,

Spice, Medicinal and Aromatic

Crops, College of Horticulture,

Dr. Y.S.R. Horticultural

University, Anantharajupeta,

Railway Kodur (Mandal),

Kadapa District, Andhra

Pradesh, India

\section{KM Yuvaraj}

Department of Plantation,

Spice, Medicinal and Aromatic Crops, College of Horticulture,

Dr. Y.S.R. Horticultural

University, Anantharajupeta,

Railway Kodur (Mandal),

Kadapa District, Andhra

Pradesh, India

\section{Vijaya Bhaskar}

Department of Plantation,

Spice, Medicinal and Aromatic

Crops, College of Horticulture,

Dr. Y.S.R. Horticultural

University, Anantharajupeta,

Railway Kodur (Mandal),

Kadapa District, Andhra

Pradesh, India

\section{Lalitha K}

Department of Agronomy, College of Horticulture,

Dr. Y.S.R. Horticultural

University, Anantharajupeta,

Railway Kodur (Mandal),

Kadapa District, Andhra

Pradesh, India

VV Padmaja

Department of Plant Physiology,

College of Horticulture,

Dr. Y.S.R. Horticultural

University, Anantharajupeta,

Railway Kodur (Mandal),

Kadapa District, Andhra

Pradesh, India

Corresponding Author:

D Mastan Vali

Department of Plantation,

Spice, Medicinal and Aromatic Crops, College of Horticulture,

Dr. Y.S.R. Horticultural

University, Anantharajupeta,

Railway Kodur (Mandal),

Kadapa District, Andhra

Pradesh, India

\section{Effect of organic manures and bio-fertilizers on yield and quality of senna (Cassia angustifolia Vahl.) cv. 'Sona'}

\author{
D Mastan Vali, KM Yuvaraj, V Vijaya Bhaskar, Lalitha K and VV \\ Padmaja
}

DOI: https://doi.org/10.22271/chemi.2020.v8.i4u.9922

\begin{abstract}
A field experiment was conducted during late kharif 2018-2019 at College of Horticulture, Anantharajupeta to evaluate the effect of different organic manures and bio- fertilizers on yield and quality of senna cv. 'Sona'. Significantly highest cumulative leaf yield of senna was observed by application of $100 \%$ RDN through vermicompost in combination with bio-fertilizers. However, significantly highest leaf yield (48.45 and $20.05 \mathrm{~g} \mathrm{~m}-2$ recorded respectively at 115 and $140 \mathrm{DAS})$ and pod yield (63.25 and $6.32 \mathrm{~g} \mathrm{~m}-2$ recorded respectively as fresh and dry pod yields) at 140 DAS in senna by application of $100 \%$ RDN through urea and was found at par with $100 \%$ RDN through vermicompost in combination with bio-fertilizers. No significant difference was recorded with respect to sennoside content of the leaves. However, significant differences were observed in the total sennoside content of pods with the application of different organic manures and bio-fertilizers at different treatment combinations. The benefit to cost ratio was found highest (2.2:1) with the application of $100 \%$ RDN through urea followed by $100 \%$ RDN through FYM in combination with bio-fertilizers viz., Azospirillum and PSB. Lowest benefit to cost ratio (1.03:1) was observed with the application of $100 \%$ RDN through vermicompost.
\end{abstract}

Keywords: Bio-fertilizers, organic manures, quality, senna, sennoside and yield

\section{Introduction}

Sennoside is an important secondary metabolite obtained from the leaves and pods of senna (Cassia angustifolia Vahl.) plant which is considered as a non-nitrogen fixing member of Leguminaceae family. Senna is considered to be native of Yemen and South Arabia and is popularly known as 'Swarnapatri'. Even though, senna is an introduced crop to India, it leads in the production and export of sennoside in the world trade and commerce by producing an average annual income to the tune of 300 million Indian rupees (Kayina and Reddy, 2012) ${ }^{\text {[5] }}$ and thus regarded as 'South Indian Dollar Earning Crop'. In India, senna is widely grown in the state of Tamil Nadu and to a smaller extent in the neighboring states of Andhra Pradesh, Telangana and Karnataka in the southern part of India and to certain extent in other states like Rajasthan, Gujarat, Maharashtra, West Bengal and Tripura. At present, senna is cultivated in an area of about 25,000 hectares (Basak and Gajbhiye, 2018) ${ }^{[1]}$ in India. It is a widely used medicinal herb in ayurveda, unani and also in the allopathic system of medicine. Leaves and pods are the economic parts of the plant which contain mainly Sennoside-A and Sennoside-B. Both sennoside-A\&B are mainly used for their laxative property. Apart from this, senna is also used as a potent cathartic, febrifuge in spleen enlargement, anemia, typhoid, tumors, foul breath, bronchitis and in curing the leprosy.

Organic fertilizer management is a key factor in the successful cultivation of medicinal and aromatic plants. Restricted usage of chemical fertilizers and inclusion of organic manures in combination with bio-fertilizers in the soil improves the fertility status and believed to encourage vegetative growth and development of the plant and economic parts of plant. Thus, usage of organics and bio-fertilizers in combination with chemical fertilizers in the form of integrated nutrient management is emphasized especially in the cultivation of medicinal plants because of ever increasing demand for organically produced herbs (Singaravel et al., 2016) ${ }^{[12]}$. 
Organic manures will enhance the soil fertility, soil structure, water holding capacity, physical and chemical properties of soil, microbial activity and nutrient availability without having undesirable effect on the environment. They also enhance the vegetative and reproductive growth of the plant. Roots of senna do not form nodules and hence cannot fix nitrogen. So, with the use of $\mathrm{N}$-fixing micro-organisms like Azospirillum, the availability of nitrogen to the plant can be increased, thus increasing the yield. Dual inoculation of Azospirillum and phosphate solubilizing bacteria (PSB) has proved an additional benefit on crop yield and also indicated a synergistic effect on quality (Okon and Gonzalez, 1994) ${ }^{[8]}$. Bio-fertilizers are harmless, low cost, renewable agricultural inputs which contain active strains of specific microorganisms which increase the productivity by increasing the availability of nutrients to the host plant. Keeping all these things in view, the present investigation was carried to find out the influence of organic manures and bio-fertilizers on leaf and pod yield as well as quality of senna cv. 'Sona'.

\section{Materials and Methods}

A field experiment was laid out at College of Horticulture, Dr. Y.S.R. Horticultural University, Anantharajupeta, Kadapa district of Andhra Pradesh to study the influence of different organic manures and bio-fertilizers on yield and quality of senna. Senna seeds of 'Sona' cultivar were obtained from the Medicinal Plants Research Station of Sri Konda Laxman Telangana State Horticultural University, Rajendranagar, Hyderabad. The seeds were sown directly in a well prepared field with a spacing of $45 \times 30 \mathrm{~cm}$ under drip irrigation. The field was laid out in a randomized block design with three replications. The treatments were $\mathrm{T} 1: 100 \%$

RDN through FYM (11.25 t ha-1); T : 100\% RDN through vermicompost (5 t ha-1); T3: 100\% RDN through neem cake (1.73 t ha-1); T4: 100\% RDN through FYM (11.25 t ha-1) in combination with Bio-fertilizers (Azospirillum + PSB); T5: $100 \%$ RDN through vermicompost (5 t ha-1) in combination with Bio-fertilizers (Azospirillum+PSB); T6: 100\% RDN through neem cake (1.73 t ha-1) in combination with Biofertilizers (Azospirillum + PSB); T : 100\% RDN through FYM (33\%@3.75 t ha1) + vermicompost (33\%@1.66 tha1)+ neem cake (33\% @ 0.57 t ha-1); T8: 100\% RDN through FYM (33\%@3.75 t ha-1) + vermicompost (33\%@1.66 t ha-1) + neem cake (33\% @ 0.57 t ha-1) + Bio-fertilizers (Azospirillum+PSB); T9: $100 \% \mathrm{RDN}$ through urea $(0.195 \mathrm{t}$ ha-1). Azospirillum and PSB were applied at the rate of $2.0 \mathrm{~kg}$ ha-1 in the treatment combinations wherever they were included. Yield attributing characters were recorded at periodic intervals at different stages of plant growth and the data were subjected to statistical analysis as applicable to randomized block design as per the procedure laid out by Gomez and Gomez (1976) ${ }^{[4]}$.

Total sennoside content (sennoside $\mathrm{A}+\mathrm{B}$ ) was estimated at Directorate of Medicinal and Aromatic Plants Research (DMAPR), Anand district of Gujarat state. Leaves and pods of senna collected from the experimental field were shadedried till we get a constant weight. A finely powdered senna leaf of $1.0 \mathrm{~g}$ weight was extracted with hexane for three times (3 $\times 25 \mathrm{ml})$ and then hexane was discarded and $25 \mathrm{ml}$ of mixture of methanol : water $(70: 30 \mathrm{v} / \mathrm{v})$ was added to the mark and suspension was left over night at room temperature $\left(25{ }^{\circ} \mathrm{C}\right)$ then extracted with methanol : water mixture for twice $(2 \times 25 \mathrm{ml})$. The extract was bulked and made up to 100 $\mathrm{ml}$ with methanol: water. An aliquot of $1 \mathrm{ml}$ extract was filtered through a sample filtration kit (PTFE; Waters,
Milford, USA) and a $10 \mu \mathrm{l}$ sample was subjected to HPLC analysis. The extraction of pods was performed exactly as described above for the leaf samples.

HPLC analysis was performed using a Waters modular system consisting of two model 501 pumps, an automated gradient controller, a model U6K injector, an in-line solvent degasser, a model 996 photodiode array detector (PAD) and Millennium 2010 chromatography management software. The injector, gradient controller and chromatography manager were integrated together to give reproducible results. A Symmetry C18 column ( 150 x 4.6 mm i.d.; $5 \mu \mathrm{m}$; Waters) was used for analysis, and spectral acquisition was performed at $285.0 \mathrm{~nm}$ after scanning the max plot of standards.

The solvent system consisted of (A) methanol: water : acetic acid (20:80:0.1, v/v/v; $\mathrm{pH} 4.0)$ and (B) methanol : water : acetic acid $(80: 20: 0.1 ; \mathrm{pH} 4.0)$. Elution was carried out at $25{ }^{\circ} \mathrm{C}$ starting at $80 \% \mathrm{~A}$ for $5.0 \mathrm{~min}$., changing to $100 \% \mathrm{~B}$ (linear gradient) over $20 \mathrm{~min}$., isocratic at $100 \%$ B for 10 min., and then changing to the initial condition over $5 \mathrm{~min}$. The flow rate was maintained at $0.6 \mathrm{ml} / \mathrm{min}$. for the first 20 min., whilst at $30 \mathrm{~min}$., it was $1.0 \mathrm{ml} / \mathrm{min}$. A calibration curve for each standard sennoside content was plotted and found to be linear over the range $2-50 \mu \mathrm{g}$ as reported earlier (Verma $e t$ al., 1996) ${ }^{[14]}$. The minimum detection limits of the method were $0.2 \mu \mathrm{g} / \mathrm{ml}$ for sennoside A and $0.1 \mu \mathrm{g} / \mathrm{ml}$ for sennoside B.

\section{Results and Discussion}

The data pertaining to yield attributes of senna were presented in Table 1. Data pertaining to leaf production in senna cv. 'Sona' showed significant differences at different intervals of data recorded. Significantly highest number of leaves per plant $(34.80,69.48$ and 98.63 respectively at 50, 75 and 90 days after sowing) was observed in senna cv. 'Sona' by application of $100 \%$ RDN through vermicompost in combination with bio-fertilizers viz., Azospirillum and PSB whereas, significantly lowest number of leaves per plant (22.83 and 52.20 respectively on 50 and 75 days after sowing) was observed by application of 100\% RDN through FYM. On day 90 , application of $100 \%$ RDN through urea recorded significantly lowest number of leaves per plant (73.19) which was found at par with all the treatments of different organic manures or their combinations only. The reason for increase in number of leaves per plant may be attributed to the cumulative effect of vermicompost and bio-fertilizers which enhanced the growth and development of senna. Similar kind of observation was reported earlier by Shakila (2013) ${ }^{[10]}$ in mint, Shinde et al. (2013) ${ }^{[1]}$ in aswagandha and Thuy and Pham (2017) ${ }^{[13]}$ in tomato. However, significantly highest number of leaves per plant i.e., 101.00 and 75.86 respectively on 115 and 140 days after sowing was observed in senna by application of $100 \%$ RDN through urea and was found at par with the application of $100 \%$ RDN through vermicompost in combination with bio- fertilizers viz., Azospirillum and PSB (100.44 and 73.07 respectively on 115 and 140 days after sowing). Significantly lowest number of leaves per plant was observed in plants treated with $100 \%$ RDN through FYM. The reason for increase in number of leaves per plant in the treatment supplied with $100 \%$ RDN through urea at 115 and 140 days after sowing might be attributed to the second and third split applications of inorganic source of nitrogen.

Significantly highest number of pods per plant (47.68) was recorded with the application of $100 \%$ RDN through urea. However, it was at par with the application of $100 \%$ RDN through vermicompost in combination with bio-fertilizers viz., 
Azospirillum and PSB (45.43). The data has evidenced that, application of $100 \%$ RDN through urea showed a beneficial effect on the number of pods per plant indicating that nitrogen had a role in accelerating the synthesis of chlorophyll and amino acids resulting in increased vegetative growth. This might have resulted in rapid synthesis, translocation and accumulation of photosynthates from source (leaves) to sink (pods) as observed by Vimala and Natarajan (2002) ${ }^{[15]}$ in pea, which might have ultimately contributed to increase in the number of pods per plant. Similar kind of observation with increased number of pods per plant by application of inorganic fertilizers was reported earlier by Brajeshwar et al. (2007) ${ }^{[2]}$ in senna.

Significant differences were observed in the leaf and pod yields of senna cv.'Sona' (Table 2) by application of different organic manures and bio-fertilizers. Significantly highest fresh leaf yield $(232.10 \mathrm{~g} \mathrm{~m}-2)$ and dry leaf yield $(54.56 \mathrm{~g} \mathrm{~m}$ 2) were observed in the plants treated with $100 \% \mathrm{RDN}$ through vermicompost in combination with bio-fertilizers viz., Azospirillum and PSB, whereas, significantly lowest fresh leaf yield (170.34 g m-2) and dry leaf yield (38.35 $\mathrm{g} \mathrm{m}-2)$ were observed in the treatment with $100 \%$ RDN applied through urea during the first harvest at 90 DAS. Significantly highest fresh leaf yield $(250.79 \mathrm{~g} \mathrm{~m}-2)$ and dry leaf yield (59.46 g m2) were recorded in the treatment with $100 \%$ RDN through urea and was found at par with the application of $100 \%$ RDN through vermicompost in combination with bio-fertilizers viz., Azospirillum and PSB during the second harvest at 115 DAS. The other organic manurial treatments in combination with bio-fertilizers recorded significantly higher yield than the organic treatments without bio-fertilizers. The trend was found similar at 140 days after sowing with regard to fresh leaf and dry leaf yields of senna. Significantly higher yield recorded with the application of $100 \%$ RDN through vermicompost in combination with bio-fertilizers viz., Azospirillum and PSB at 90 days after sowing was mainly due to put up of highest plant height, number of branches per plant (data were not shown) and number of leaves per plant. This might be due to increased availability of nutrients and other growth promoting substances supplied through organic manures and bio-fertilizers mainly the vegetative growth promoting nutrient nitrogen. Nitrogen is considered as the chief constituent of many substances which include amino acids and proteins and is essential for formation of protoplasm, cell division, cell enlargement and thus nitrogen is an important nutrient for higher leaf yield. This might be the reason for a significant increase in the leaf yield of senna by the application of $100 \%$ RDN through urea and $100 \%$ RDN through vermicompost in combination with biofertilizers viz., Azospirillum and PSB. Specially, application of nitrogen in split doses at 90 days after sowing helped the crop to survive better and yield more leaves. Continuous supply of nutrients through organic manures coupled with bio-fertilizers might have enhanced the vegetative growth and leaf yield in senna. Similar kind of observation was reported earlier by Kayina and Reddy (2012) ${ }^{[5]}$ and Kumar and Kumar (2018) ${ }^{[6]}$ in senna. The fresh and dry leaf yields at 3rd harvest were lower when compared to 1 st and 2 nd harvests. The reason might be due to stripping of leaves earlier i.e., in the 1 st and 2 nd harvest and also because of reduced crop growth rate due to ageing.

Significantly highest fresh and dry pod yields in senna cv.'Sona' was obtained by application of $100 \%$ RDN through urea $(95.02$ and $9.50 \mathrm{~g} \mathrm{~m}-2$ respectively as fresh and dry pod yields) and was found at par with the application of $100 \%$ RDN through vermicompost in combination with biofertilizers viz., Azospirillum and PSB. Increased yield in senna pods might be attributed to increased plant height, number of branches per plant (data were not shown), number of leaves per plant and increased number of pods per plant. Similar kind of observation was also reported earlier by Magesh (2004) ${ }^{[7]}$ and Singaravel et al. (2016) ${ }^{[12]}$ in senna and Darzi et al. (2012) ${ }^{[3]}$ in anise.

The data pertaining to quality of senna leaves and pods by application of different organic manures and bio-fertilizers was presented in Table 3. Data pertaining to yield of sennoside content in the leaves of senna cv. 'Sona' has shown non-significant differences among the treatments at all the three harvests. Slight differences observed among the treatment combinations might be attributed to the presence of more number of younger leaves. Similar kind of observation was reported earlier by Rao (2008) ${ }^{[9]}$ in senna. However, significant differences were observed in the total sennoside content of pods with the application of different organic manures and bio-fertilizers at different treatment combinations. Among the treatments, application of $100 \%$ RDN through vermicompost in combination with biofertilizers viz., Azospirillum and PSB recorded significantly highest total sennoside content $(3.50 \%)$ in the pods and was found at par with the application of $100 \%$ RDN through urea, $100 \%$ RDN through FYM+vermicompost+neem cake in combination with bio-fertilizers viz., Azospirillum and PSB and $100 \%$ RDN through neem cake with bio-fertilizers viz., Azospirillum and PSB. Significantly lowest total sennoside content $(3.39 \%)$ of pods was noticed with the application of $100 \%$ RDN through FYM. Differences observed in the total sennoside content of pods might be attributed due to the presence of more number of younger pods in the treatments which contained bio- fertilizers apart from different organic manures excepting 100\% RDN through FYM in combination with bio-fertilizers. However, split application of $100 \%$ RDN through urea without any biological agent caused better utilization by the plant thus produced more number of pods per plant and total sennoside content. As the pods got older, its sennoside content got reduced due to increased fiber content in the pods. Similar kind of result was reported earlier by Magesh (2004) ${ }^{[7]}$ in senna.

Highest benefit to cost ratio (2.2:1) was observed with the application of $100 \%$ RDN through urea. The next best benefit to cost ratio $(1.58: 1)$ was noticed with the application of $100 \%$ RDN through FYM in combination with bio-fertilizers viz., Azospirillum + PSB. Lowest benefit to cost ratio (1.03:1) was observed with the application of $100 \%$ RDN through vermicompost. 
Table 1: Influence of organic manures and bio-fertilizers on yield of leaves and pods per plant in senna (Cassia angustifolia Vahl.) cv. 'Sona'

\begin{tabular}{|c|c|c|c|c|c|c|}
\hline \multirow{2}{*}{ Treatment } & \multicolumn{5}{|c|}{ Number of leaves/plant } & \multirow{2}{*}{\begin{tabular}{|c|}
$\begin{array}{c}\text { Number of } \\
\text { pods per plant }\end{array}$ \\
140 \\
DAS \\
\end{tabular}} \\
\hline & \begin{tabular}{c|c|}
$\mathbf{5 0}$ \\
DAS
\end{tabular} & $\begin{array}{c}75 \\
\text { DAS }\end{array}$ & $\begin{array}{c}90 \\
\text { DAS }\end{array}$ & 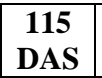 & $\begin{array}{c}\text { 140 } \\
\text { DAS }\end{array}$ & \\
\hline 100\% RDN through FYM (11.25 t ha-1) & 22.83 & 52.20 & 75.28 & 76.27 & 55.00 & 27.42 \\
\hline $100 \%$ RDN through Vermicompost (5 t ha-1) & 23.96 & 52.46 & 75.80 & 76.92 & 56.52 & 28.81 \\
\hline $100 \%$ RDN through Neem cake (1.73 t ha-1) & 23.42 & 52.23 & 74.41 & 76.60 & 55.64 & 27.99 \\
\hline 100\% RDN through FYM (11.25 t ha-1) + Bio-fertilizers (Azospirillum + PSB) & 28.08 & 60.34 & 85.27 & 86.92 & 64.61 & 35.29 \\
\hline $100 \%$ RDN through Vermicompost (5 t ha-1) + Bio-fertilizers (Azospirillum + PSB) & 34.80 & 69.48 & 98.63 & 100.44 & 73.07 & 45.43 \\
\hline 100\% RDN through Neem cake (1.73 t ha-1) + Bio-fertilizers (Azospirillum +PSB) & 29.47 & 61.09 & 86.81 & 87.20 & 65.26 & 36.07 \\
\hline $\begin{array}{c}100 \% \text { RDN through FYM (33\% @ 3.75 tha1) + Vermicompost (33\% @ } 1.66 \mathrm{t} \text { ha-1) + } \\
\text { Neem cake (33\% @ 0.57 t ha-1) }\end{array}$ & 23.60 & 53.60 & 75.86 & 76.83 & 56.22 & 28.27 \\
\hline $\begin{array}{c}\text { 100\% RDN through FYM (33\% @ 3.75 t ha-1)+ Vermicompost (33\% @ } 1.66 \mathrm{t} \text { ha-1) + } \\
\text { Neem cake (33\% @ } 0.57 \mathrm{t} \text { ha-1) + Bio-fertilizers (Azospirillum + PSB) }\end{array}$ & 29.16 & 60.76 & 86.65 & 87.01 & 64.85 & 35.86 \\
\hline $100 \%$ RDN through Urea $(0.195 \mathrm{t}$ ha- 1$)$ & 23.20 & 52.82 & 73.19 & 101.00 & 75.86 & 47.68 \\
\hline $\mathrm{CD}(P=0.05)$ & 5.23 & 7.74 & \begin{tabular}{|l|}
10.09 \\
\end{tabular} & 9.40 & 6.55 & 5.41 \\
\hline $\mathrm{SEm} \pm$ & 1.73 & 2.56 & 3.33 & 3.10 & 2.16 & 1.79 \\
\hline
\end{tabular}

Table 2: Influence of organic manures and bio-fertilizers on fresh \& dry leaf yield as well as fresh \& dry pod yield in senna (Cassia angustifolia Vahl.) cv. 'Sona'

\begin{tabular}{|c|c|c|c|c|c|c|c|c|}
\hline \multirow{3}{*}{ Treatment } & \multicolumn{6}{|c|}{ Leaf yield (g m-2) } & \multicolumn{2}{|c|}{ Pod yield (g m-2) } \\
\hline & \multicolumn{3}{|c|}{ Fresh } & \multicolumn{3}{|c|}{ Dry } & \multirow{2}{*}{\begin{tabular}{|c|c} 
Fresh \\
140 \\
DAS
\end{tabular}} & \multirow{2}{*}{$\begin{array}{c}\text { Dry } \\
140 \\
\text { DAS }\end{array}$} \\
\hline & \begin{tabular}{c|c}
90 \\
DAS
\end{tabular} & $\begin{array}{c}115 \\
\text { DAS }\end{array}$ & 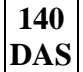 & 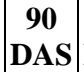 & 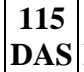 & \begin{tabular}{c|c|}
140 \\
DAS
\end{tabular} & & \\
\hline 100\% RDN through FYM (11.25 t ha-1) & 172.13 & 190.17 & 68.29 & 39.99 & 48.45 & 20.05 & 63.27 & 6.32 \\
\hline $100 \%$ RDN through Vermicompost (5 t ha-1) & 174.38 & 193.26 & 70.78 & 40.75 & 50.02 & 20.93 & 64.72 & 6.47 \\
\hline $100 \%$ RDN through Neem cake (1.73 t ha- 1$)$ & 173.56 & 191.51 & 69.52 & 40.05 & 49.79 & 20.41 & 64.31 & 6.43 \\
\hline $100 \%$ RDN through FYM (11.25 t ha-1) + Bio- fertilizers (Azospirillum + PSB) & 197.72 & 212.68 & 79.58 & 48.30 & 53.00 & 24.90 & 74.14 & 7.41 \\
\hline $100 \%$ RDN through Vermicompost (5 t ha- 1$)+$ Bio-fertilizers (Azospirillum + PSB) & 232.10 & 243.16 & 90.14 & 54.56 & 57.82 & 27.99 & 91.53 & 9.15 \\
\hline $100 \%$ RDN through Neem cake (1.73 t ha-1) + Bio-fertilizers (Azospirillum +PSB) & 201.65 & 216.19 & 81.21 & 49.42 & 53.68 & 25.30 & 76.36 & 7.63 \\
\hline $\begin{array}{c}\text { 100\% RDN through FYM (33\% @ } 3.75 \text { t ha1) + Vermicompost (33\% @ } 1.66 \mathrm{t} \text { ha- } 1)+ \\
\text { Neem cake (33\% @ } 0.57 \mathrm{t} \text { ha- } 1)\end{array}$ & 173.02 & 190.4 & 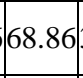 & 39.10 & 49.10 & 20.28 & 64.57 & 6.45 \\
\hline $\begin{array}{c}\text { 100\% RDN through FYM (33\% @ } 3.75 \text { t ha-1)+ Vermicompost (33\% @ } 1.66 \mathrm{t} \text { ha-1)+ } \\
\text { Neem cake (33\% @ } 0.57 \mathrm{t} \text { ha-1) + Bio-fertilizers (Azospirillum + PSB) }\end{array}$ & 1 & 215.9 & 80.4 & 4008 & 53.39 & 5.11 & 74.39 & 7.43 \\
\hline $100 \%$ RDN through Urea (0.195 t ha- 1$)$ & 170.34 & 250.79 & 92.65 & 38.35 & 59.46 & 28.53 & \begin{tabular}{l|l}
395.02 \\
\end{tabular} & 9.50 \\
\hline $\mathrm{CD}(P=0.05)$ & 12.57 & 13.90 & 4.18 & 2.90 & 2.32 & 1.74 & 4.01 & 0.83 \\
\hline SEm \pm & 04.15 & 04.59 & 1.38 & 0.96 & $\mid 0.77$ & 0.57 & 1.32 & 0.27 \\
\hline
\end{tabular}

Table 3: Influence of organic manures and bio-fertilizers on the total sennoside content of leaves and pods and benefit to cost ratio in senna (Cassia angustifolia Vahl.) cv. 'Sona'

\begin{tabular}{|c|c|c|c|c|c|}
\hline \multirow[t]{2}{*}{ Treatment } & \multicolumn{3}{|c|}{$\begin{array}{l}\text { Total sennoside content of } \\
\text { leaves }(\%) \text { during different } \\
\text { days of harvest }\end{array}$} & \multirow{2}{*}{\begin{tabular}{|c|}
$\begin{array}{c}\text { Total sennoside } \\
\text { content of pods } \\
(\%)\end{array}$ \\
140 DAS \\
\end{tabular}} & \multirow{2}{*}{$\begin{array}{c}\text { Benefit to Cost } \\
\text { Ratio in the } \\
\text { cultivation of } \\
\text { senna } \\
\end{array}$} \\
\hline & 90 DAS & 115 DAS & 140 DAS & & \\
\hline $100 \%$ RDN through FYM (11.25 t ha-1) & 1.49 & 1.51 & 1.44 & 3.39 & $1.37: 1$ \\
\hline $100 \%$ RDN through Vermicompost (5 t ha- 1 ) & 1.51 & 1.54 & 1.44 & 3.41 & 1.03:1 \\
\hline $100 \%$ RDN through Neem cake (1.73 t ha-1) & 1.51 & 1.53 & 1.44 & 3.43 & $1.22: 1$ \\
\hline $\begin{array}{c}100 \% \text { RDN through FYM (11.25 t ha-1) + Bio-fertilizers (Azospirillum + } \\
\text { PSB) }\end{array}$ & 1.50 & 1.52 & 1.55 & 3.41 & $1.58: 1$ \\
\hline $\begin{array}{l}100 \% \text { RDN through Vermicompost (5 t ha-1) + Bio-fertilizers } \\
\text { (Azospirillum + PSB) }\end{array}$ & 1.52 & 1.54 & 1.44 & 3.50 & $1.30: 1$ \\
\hline $\begin{array}{l}100 \% \text { RDN through Neem cake (1.73 t ha-1) + Bio-fertilizers } \\
\text { (Azospirillum +PSB) }\end{array}$ & 1.51 & 1.54 & 1.44 & 3.48 & $1.41: 1$ \\
\hline $\begin{array}{l}100 \% \text { RDN through FYM (33\% @ } 3.75 \text { t ha1) + Vermicompost (33\% @ } \\
1.66 \text { t ha-1)+ Neem cake (33\% @ } 0.57 \mathrm{tha}-1)\end{array}$ & 1.50 & 1.52 & 1.44 & 3.45 & $1.18: 1$ \\
\hline $\begin{array}{c}\text { 100\% RDN through FYM (33\% @ } 3.75 \mathrm{t} \text { ha-1) + Vermicompost (33\% @ } \\
1.66 \mathrm{t} \text { ha-1) + Neem cake (33\% @ } 0.57 \mathrm{t} \text { ha-1) + Bio-fertilizers } \\
\text { (Azospirillum + PSB) }\end{array}$ & 1.52 & 1.53 & 1.44 & 3.49 & $1.37: 1$ \\
\hline $100 \%$ RDN through Urea $(0.195 \mathrm{t}$ ha- 1$)$ & 1.51 & 1.50 & 1.55 & 3.49 & $2.20: 1$ \\
\hline $\mathrm{CD}(P=0.05)$ & NS & NS & NS & 0.04 & -- \\
\hline SEm \pm & 0.006 & 0.008 & 0.003 & 0.01 & -- \\
\hline
\end{tabular}




\section{References}

1. Basak BB, Gajbhiye NA. Phosphorous enriched organic fertilizer, an effective $\mathrm{P}$ source for improving yield and bioactive principle of senna (Cassia angustifolia Vahl.). Industrial Crops and Products. 2018; 115:208-213.

2. Brajeshwar A, Joshi AK, Dey S. Effect of kunapajala and fertilizers on senna (Cassia angustifolia Vahl.). Indian Forester (September issue): 2007, 1235-1240.

3. Darzi MT, Seyedhadi M, Farhad R. Effects of application of vermicompost and phosphate solubilizing bacterium on the morphological traits and seed yield of anise (Pimpinella anisum L.). Journal of Medicinal Plant Research. 2012; 6(2):215-219.

4. Gomez KA, Gomez AA. Statistical procedures for agricultural research. John Wiley \& Sons, New York. 1976,680

5. Kayina BD, Reddy GS. Effect of organic manures, biofertilizers and inorganic fertilizers on growth and yield of senna (Cassia angustifolia Vahl.). The Asian Journal of Horticulture. 2012; 7(1):144-147.

6. Kumar ACJ, Kumar TP. Effect of different proportions of fly ash and vermicompost on growth and yield of senna in semi arid regions of India. Journal of Pharmacognosy and Phytochemistry. 2018; 3:69-72.

7. Magesh. Effect of organic manures on senna (Cassia angustifolia Vahl.). M.Sc. (Ag.) Thesis submitted to Acharya N.G. Ranga Agricultural University, Hyderabad, India, 2004.

8. Okon Y, Gonzalez LCA. Agronomic applications of Azospirillum: An evaluation of 20 years worldwide field inoculation. Soil Biology and Biochemistry. 1994; 26:1591-1601.

9. Rao. Studies on the effect of organic and bio-nutrient sources on growth, productivity and quality in senna (Cassia angustifolia Vahl.) and their residual effect on succeeding roselle (Hibiscus sabdariffa L.) crop. Ph.D. Thesis submitted to Acharya N.G. Ranga Agricultural Universitty, Hyderabad, India, 2008.

10. Shakila A. Studies on organic nutrition in growth and yield of Japanese mint (Mentha arvensis L.). Asian Journal of Horticulture. 2013; 8(1):126-128.

11. Shinde, Gahunge P, Singh P, Rath SK, Naresh K. Effect of inorganic fertilizers and organic manures on growth, quality and yield of ashwagandha (Withania somnifera Dunal) cv. Jawahar Ashwagandha-20. Annals of Pharmacy and Pharmaceutical Sciences. 2013; 4(1, 2):1316.

12. Singaravel R, Elayaraja D, Viswanathan K. Effect of integrated nutrient management on the growth and yield of senna in coastal sandy soils. An Asian Journal of Soil Science. 2016; 11(1):187-190.

13. Thuy NP, Pham TD. Effect of vermicompost levels on the growth and yield of HT152 tomato variety grown organically. International Journal of Agriculture Innovations and Research. 2017; 5(4): 1-6.

14. Verma RK, Uniyal GC, Singh SP, Sharma JR, Gupta MM. Reverse-phase high performance liquid chromatography of sennosides in Cassia angustifolia. Phytochemical Analysis. 1996; 7:73-75.

15. Vimala B, Natarajan S. Studies on certain physiological parameters in pea (Pisum sativum L.) as influenced by $\mathrm{N}$, $P$ and bio-fertilizers. South Indian Journal of Horticulture. 2002; 50(4-6):387-391. 